\title{
Educating young people through Christian youth worship: Reclaiming space for learning in liturgical contexts
}

\begin{abstract}
Authors:
Ronelle Sonnenberg ${ }^{1}$

Marcel Barnard ${ }^{1,2}$

\section{Affiliations:}

${ }^{1}$ Department of Practical

Theology, Protestant

Theological University, The

Netherlands

${ }^{2}$ Department of Practical

Theology, University of

Pretoria, South Africa

Note:

Prof. Dr Marcel Barnard is participating as research associate of Prof. Dr Cas

Wepener, Department of Practical Theology, University of Pretoria, South Africa.

This article is published in the section Practical Theology of the Society for Practical Theology in South Africa.

Correspondence to: P.M. (Ronelle) Sonnenberg

Email:

pmsonnenberg@pthu.nl

Postal address:

PO Box 80105, 3508 TC

Utrecht, The Netherlands

Dates:

Received: 10 June 2011

Accepted: 21 Sept. 2011

Published: 13 Mar. 2012

How to cite this article: Sonnenberg, P.M. \& Barnard, M., 2012, 'Educating young people through Christian youth worship: Reclaiming space for learning in liturgical contexts', HTS Teologiese Studies/Theological Studies 68(2), Art. \#1111, 8 pages. http://dx.doi.org/10.4102/ hts.v68i2.1111
\end{abstract}

C 2012. The Authors. Licensee: AOSIS OpenJournals. This work is licensed under the Creative Commons Attribution License.
This article dealt with the relationship between education and youth worship in Protestant contexts in the Netherlands. Consequently, it dealt with the relation between Liturgical and Educational Studies. Our interest in the research project on youth worship in Protestant contexts centred on the question: How do young people, in a late-modern context, participate in youth worship? In our qualitative research, it appeared that 'learning' is a key word with regard to youth worship. This article discussed the questions: How are youth worship and 'learning faith' related? And, what are the qualities of learning faith in youth worship? Empirical results of the research in local youth worship services and national youth worship events were presented. These results concentrated on the dialogical dimension in youth worship gatherings and gave indications about the contents of what adolescents learn in youth worship gatherings. This 'what' referred, amongst other aspects, to the important content of 'rules and freedom'. Respondents often valued and appropriated youth worship along the line of '(do not) have to', with regard to a Christian life style, their relation with God, ethics, and doctrines. Moreover, themes in youth worship gatherings often focused on a specific Christian lifestyle, on its boundaries and its spaces. Some reflections with regard to the question 'Why is learning faith a dominant element in youth worship?' were given. The conclusions that the cognitive element is important in youth worship and that the explicit aspect of learning is a main approach in youth worship were discussed in relation to J. Astley's (1984) theoretical notion that the language of worship is 'performing non-cognitive'.

\section{Introduction}

This article deals with the relationship between youth worship and education and, as a consequence, the relation between Liturgical and Educational Studies. We use the concept of 'learning faith' as the basis for this research, considering it a building block in Christian education. We will present empirical results concerning 'learning faith' in youth worship gatherings in local services, national events and one European event. The main question we wish to answer in this article is: How are youth worship and 'learning faith' related and what are the qualities of 'learning faith' in youth worship?

Firstly, we delineate briefly worship as a learning environment, outlining youth worship and explaining the context of our research project. Our starting point is the thesis of J. Astley (1984), which argues that explicit learning in Christian education requires a spiritual and ritual embedding. The debate whether liturgical ritual has certain functions or is an end in itself is also introduced in the first section. Secondly, we provide an explanation of the concept of 'learning faith', describing it from educational and practical theological perspectives. In this article we combine both of these discourses. Thirdly, we present an overview of the results of the analysis of the empirical data, whilst, fourthly, we reflect on and explain the important relation between learning faith and youth worship. Finally, we formulate some conclusions with regard to the educational, functional quality of youth worship.

\section{Research context Worship as a learning environment}

To describe the formative power of Christian worship in becoming Christians, we refer to an article by J. Astley published in 1984 entitled, 'The role of worship in Christian learning'. Astley (1984:249) argues that worship is a learning environment in which 'God can be "seen" and "heard"' both psychologically and epistemologically. Astley (1984:245) refers to Ninian Smart, who maintains that worship is expressive as well as evocative, in that it expresses religious attitudes, affections and experiences and evokes them at the same time. We would like to assert that worship is both a product and a producer of existential Christian features, or of a Christian habitus. Astley (1984:243-245) states that much of Christian learning is brought about through explicitly systematic activities, which lead to the development of knowledge of Christian beliefs. He contrasts this with the learning process in liturgy that initially does not include cognitive 
elements and he concludes that the language of worship is foremost 'performing non-cognitive' rather than cognitive and that the language in worship does not assert facts or provide descriptions. Primarily, language creates basic attitudes for being a Christian and only within this spiritual framework can there also be an overt, explicitly cognitive aspect. In addition, we say there is always a cognitive aspect, specifically in the lessons, the preaching and other rubrics of worship, in short, when the Christian story is told, proclaimed and performed. Astley (1984) concludes that:

through the implicit catechesis of liturgy, we come to learn the Christian mode of being in the world as our attitudes, emotions, and experiences are formed through the symbolic power of ritual and ceremonial. There it is that we become fully Christian. (p. 251, [Authors' own emphasis])

We consider it an important insight that learning should not be isolated from a spiritual and performing dimension. The eventual conclusions of our research project 'God talk, between beat and silence. Youth worship in Protestant contexts' (Sonnenberg \& Barnard 2008) will be elaborated in three concepts: 'learning faith', 'embodied engagement' and 'relating to a faith community'. These concepts are considered qualities of 'participation' (see below) and are interrelated notions. It is important to keep this in mind, because in this article we focus on only one concept, namely, 'learning faith' and especially the verbal-discursive elements of worship. The reason for this focus is that it is a dominant aspect for respondents, especially of youth worship services, although this aspect is not found lacking in youth worship events either.

The importance of learning in youth worship leads us into the debate of the functionality of youth worship. On the one hand, Astley agrees with the main discourse in Liturgical Studies, namely, that liturgy is principally a non-functional discourse. On the other hand, this does not rigidly mean for Astley that there are no functional side effects of liturgy. Barnard and Wepener (work in progress, to be submitted for publication during 2012) discuss the cracks they see developing in what they call 'the maxim' of the uselessness of liturgical ritual. They focus, amongst other things, on the formative function of liturgical ritual. In this article we also point to the educational functionality of youth worship.

\section{Research domain and questions}

Youth worship gatherings can be considered a special form of worship, because of their specific characteristic of 'youth'. Of course, youth worship is not an independent phenomenon, but is related to other worship gatherings, to the church, to youth cultures, et cetera. In categorical youth worship, mainly young people participate, whereas in integrated youth worship, there is a mixture of adults and young people, though with an emphasis on young people. The domain of our research project concerns itself not only with youth worship services in a local congregation, either in either small groups or larger communities, but also national and international youth worship events. The subject of the research project is the faith of adolescents in relation to youth worship. The research question that we formulated to gain insight into this relation is: How do adolescents participate in youth worship? We speak of liturgical-ritual elements concerning youth worship, because it indicates a culturaltheological approach. 'Faith' is not defined in advance, but its meaning will be distilled from interviews and participant observations. We regard faith as a broad concept: it has cognitive, affective, social, psychological, mystagogical, physical and behavioural aspects.

An important aspect in this empirical study is the perspective of adolescents. The present study comprises qualitative research, in which the methods of participant observation and different kinds of interviews (speed, in-depth, group and individual) were used. Also (digital) documents, public relations communications and advertising with regard to worship were analysed. From 2007 to 2010, we observed 17 youth worship gatherings, 12 of which were in local congregations in the Protestant Church in the Netherlands (3 of the congregations we visited twice), 1 had a regional function, whereas 3 were national Christian youth events and 1 a European event. The youth worship events were all based in the Netherlands; they were: XMasProof, organised by the youth organisation of the Protestant Church in the Netherlands (JOP), EO-youth day (a day of the Evangelical Broadcasting Company), XNoizz Flevo Festival organised by Youth for Christ, together with EO and JOP, and the European Taizé Event.

The respondents all have a Protestant background, which, in this research project, refers to a connection with the Protestant Church in the Netherlands (PKN). This Church is a merger of churches of Reformed and Lutheran traditions and consists of mainstream congregations, conservative wings with traditional or evangelical influences, as well as liberal wings. In reality, however, many congregations have a mix of different theological and sociological perspectives and, generally speaking, adolescents have no exact knowledge of the theological characteristics of their congregation. The respondents are mainly White young people, as are the other participants in the youth worship gatherings. Their level of education ranges from lower practical education to higher academic, although many respondents are highly educated. Our research focuses on adolescents between the ages of 15 and 19 years.

In the explorative phase of the research, 'learning' became a sensitising concept. We received answers such as: 'The highlight was the discussion. I learned from the others' or 'the worship service did not yield much, because I did not learn much, I knew many things already'. We further explored the concept of learning in academic literature and brought in the literature in relation to the data and vice versa. Because of the subject of this study, namely the relation between youth worship and the faith of adolescents, the sensitising concept of 'learning' acquired the subject of faith: learning faith. Thus, we understand 'learning faith' to be a discovery of meaning and relationship, as will be elaborated in the next section. 


\section{Learning faith}

In this section we offer a theological reflection on 'learning faith' and discuss some educational theories.

\section{Theological reflection: 'Discovery'}

For a theological reflection on 'learning faith', we prefer to quote Roebben $(2007: 111,120)$ and speak of learning faith as a 'discovery of meaning'. Learning is discovering meanings that are presented in liturgy, the Bible, tradition, culture and by peers and adults and so we name this process of acquiring theological knowledge a 'discovery of meaning' in its own right. These discoveries of meanings are made in youth worship gatherings. In our theological and liturgical reflection, we do not consider the discovery of meaning as the final learning product, for the final discovery is the existential relationship between God and the individual. Adolescents give meaning to their liturgical experiences, but what they discover, is - in the end - not a meaning, but a specific relationship. This meaning can be considered as theological knowledge because it can be located in the relation between God and the worshipper; that is, in the dynamics of God's revelation to humanity and the individual's response to that revelation. It is about the 'Word heard and answered' (Barnard 1998:216). Or, stressing the interaction from two perspectives, it is about the Word as the Word spoken and answered.

Concerning liturgical-ritual elements, the interaction between God and humanity is understood and expected. This interaction depends on both the work of the Holy Spirit and the individual's act of faith; there is reciprocity. A.A. van Ruler (1908-1970) speaks of 'indwelling' and of 'God's Spirit communicating not only to us or in us, but also by means of our spirits' (Van Ruler 1972:90). The process of appropriating the Word can be considered a learning product and requires the dynamic relation in liturgical ritual of reception and production. This reciprocity means a different meta-theoretical approach from the one stating that people construct consolidation, encouragement, or insight. Faith knowledge is primarily given and either discovered or not discovered. In this discovery, God's motion toward us, in other words, his revelation, has priority; there is a theonomous reciprocity (Van Ruler 1969:181, 186). To phrase it in a classically Reformed way: the covenant is monopleuric (one-sided) in origin and dipleuric (two-sided) in existence.

\section{Learning in the light of Educational Studies}

The empirical data and literature on 'situated learning' and 'social learning' (e.g. Lave \& Wenger 1991) challenged us to regard 'learning' not only as a dimension of internalisation or as a product - which is the classical approach - but also as a learning process, or, in the present study, as a learning impulse. We introduce the concept of 'learning faith', which is meant to cover both the dimensions of the learning impulse and the learning product. This notion is open to different qualities of learning: learning into, learning from and learning about. Because our research project concerns learning in the context of worship, in which learning is an implicit process, we do not speak of a learning process, but of learning impulses; a learning process requires an intentional learning and an active reflection of the learner on the process. In youth worship, however, no portfolios with regard to the individual's learning process are produced by adolescents and the learning process can be seen as far less intentional than in a school situation. The research project uses a qualitative methodology in that we do not 'measure' starting points and outcomes of knowledge. We have preferred to research the perspective of participating adolescents and what they said they have learned or wanted to learn. In addition to the interview data, we have the data from our observations of the way in which adolescents participated in youth worship gatherings. In brief, we focus on learning impulses, the descriptions of which are based on participant observations and on interviews.

Lave and Wenger $(1991: 10,22)$ emphasise the importance of co-participants in learning, but also argue 'the way to maximize learning is to perform, not to talk about it'. Performing and participation are also recent dominant perspectives in German didactics (eds. Klie \& Leonhard 2008) and in Dutch Religious Education (Hermans 2001:203; Miedema 2002). This emphasis on the performative character of learning connects with the stress Astley puts on the idea that 'performing non-cognitive' is the first role of worship in Christian learning. Another crucial concept with regard to learning is appropriation. This is elaborated on by Siebren Miedema (2002), who uses the approach of appropriation to contrast the model of knowledge-transmission. The starting point in the model of appropriation, also named the model of transformation, is the importance of the construction of meanings and facts (Miedema 2002:93). However, as mentioned before, we prefer to speak about 'discovery of meaning' over 'construction of meaning'.

The respondents have stimulated us to regard learning products not only as factual information on the Bible, beliefs and traditions, but also as the discovery of pluralism in Christian congregations and in the sources of the Christian faith, new discoveries concerning God, as well as religious and ethical applications. These products will be described in the results of our empirical research and relate to what respondents tell about that which they have learned or that of which they have become aware. Eventually, the establishment and maintenance of the existential relationship between God and humanity is the final learning product. We are often not able to conclude, however, whether an utterance with regard to learning is an existential learning product, whether it is a learning into, or 'only' a learning about. As a result, we can only give an indication that existential learning has taken place. Moreover, it appears to be difficult for adolescents themselves to characterise existential learning in the relationship between God and humanity.

\section{Results of the data analysis}

In this section, some empirical results are presented. We distinguish between learning impulses and learning 
products. As was said before, when reading the empirical results it is important to keep in mind that learning faith, embodied engagement and relating to a faith community are considered as interrelated concepts, which means that 'learning faith' connects smoothly with 'embodied engagement' and 'relating'.

\section{Learning impulses}

Important learning impulses that adolescents mention are: discussions, sermons, other speeches and sometimes a song text. Some youth worship services are obviously based on the regular liturgical order of the congregation, but some innovations can be introduced. Often a sermon is a central element in the order of youth worship service. Other youth worship services have a particular, invented order. Different kinds of interaction are employed: theatrical performances and plays, a short Bible reading followed by a group discussion about the theme of the worship, instead of a monologue form of speech. At the various festivals, speeches, debates and lectures are juxtaposed with music and other activities. Adolescents are permitted to choose whether they join a debate, lecture or speech. In what follows, we describe six learning impulses in youth worship - some more theoretically loaded than others - that are important in relation to learning faith.

\section{Dialogical}

It is remarkable that adolescents display a highly appreciative manner when given the opportunity to engage in discussion as part of youth worship gatherings. In some youth worship services, one could even assert that a new 'tradition' has developed. Discussing a theme, learning from the convictions and experiences of others, as well as recognising the position of others, in other words, the dialogical process, are often mentioned and can be considered qualities of learning in youth worship gatherings. These conversations do not only take place during the gathering, but also in an (organised) meeting afterwards, for example a discussion about the sermon in some conservative congregations. Adolescents regard these dialogues during the liturgy as important and some contrast such dialogues with a sermon in a 'regular' service that is often experienced as a monologue. One of the arguments is that a dialogue is richer than 'only knowing the opinion of a minister' and that it 'stimulates your thinking'. The analysis of the data underscores the fact that the discussions, debates and collective exploration challenge adolescents to formulate their own convictions and experiences. The drawback is that adolescents may experience the requirement to express themselves in such a discussion as threatening, as appeared on one occasion.

\section{Cognitive and reflexive}

Adolescents mention (critical) thinking about a topic as an activity in which they are involved, either during a speech act or in silence. This process of gathering knowledge is primarily about knowledge of a specific theme or perspective on faith. Cognitive knowledge should not only be considered as rational knowledge. It is gathering new insight in a broader way, acquiring new creative ideas and information, and using the imagination. This reflexive dimension is occasionally also connected with silence. One adolescent stresses the silence as a moment for concentration and thinking, whereas another speaks about silence 'as a time to reflect on things'. Cognitive and reflexive impulses matter, especially in local communities. It is less dominant in the reflections on youth events, but it is not absent.

\section{Personalising and actualising}

We summarise the important qualities that adolescents mention with regard to a sermon - often written as 'sermon' to indicate that it differs from a regular sermon - or a speech, in the qualities of personalising and actualising. This includes the need for personal stories, practical examples and examples or questions that relate to issues encountered in daily life.

\section{'Learning by doing' and experiential learning}

One of the functional qualities of liturgical-ritual is that liturgy helps to develop skills, for example performing skills and discussing skills. Adolescents do not mention 'learning by doing' themselves, it is a more theoretically loaded qualification, but in the participant observations and some interviews it is apparent that adolescents learn by formulating their own points of view, by performing rituals, et cetera. This can be done through official performances such as reading the Bible, but less formal experiential forms are also practised, for example painting a Bible text. As such, we speak of learning by doing and experiential learning. Learning by doing indicates that people can learn by doing things, for example adolescents can learn by preparing a prayer. Meaning-making from a direct experience can be described as experiential learning and related to this is experiential education, such as theatrical performances from the pulpit with a burning arrow to illustrate Ephesians 6, or a performance of a beggar by a youth leader to introduce the theme of mercy. This form of education takes place in the relationship between a youth leader and an adolescent. Adolescents who have an 'official' task can existentially and positively experience the specific performance, but performing this task may also cause stress, which can block other experiences.

\section{Appreciation of pluralism}

Closely related to the impulse of dialogue, is the appreciation of pluralism. Adolescents primarily mention the impulse of pluralism: 'you can learn from people who have other ideas'. This can be heard during national youth events, as well as in local congregations where people also have different points of view and come from different backgrounds. In relation to this, however, it can be said that adolescents learn that in faith there is room for pluralism and that other perspectives on the Bible and on faith are possible and valuable. Here, impulse and product are related. Therefore, this element can also be described as a 'learning product'. 


\section{Investment in faith}

An interesting question is whether adolescents in the process of 'learning by doing' may also learn who God is. In the section titled 'Discussion', we propose that conversation and application may be regarded as a 'mediation of salvation'. We do not have explicit data for this supposition, but references to the importance of concentration, investing time, and openness in relation to faith support the existence of a connection between 'doing' and faith or even 'doing' and God. We suppose that 'doing' creates space for the communication between God and the individual, although we cannot 'prove' this. We will reflect further on this element in a future article about 'embodied engagement'.

\section{Learning products}

We now move on to the five learning products or learning contents we identified primarily on the basis of the interviews with adolescents. These products are, of course, related to the learning impulses: the distinction is provisional.

\section{Information and support}

Adolescents appreciate it when they acquire new knowledge and information. They prefer clarity on questions and topics. One adolescent speaks of 'the information that the minister gives about God', another mentions 'the information about what Pentecost is'. Affective knowledge refers to encouragement, support and affirmation, challenges, and motivation. In this research, the aspect of the discovery of a supportive, affirmative, motivating community is especially connected with the experience of belonging to a faith community. So, there is some overlap between 'learning faith' that includes affective learning and 'relating to a community', which includes support by the community. The learning product 'support' concentrates on the quotations that relate encouragement and challenges to (new) insights. This can be insights with regard to desires and needs of adolescents and their identity. Remarks which we believe demonstrate support as a learning product are for example that for someone it is important to hear others saying that God loves him. He feels supported. Or a respondent who said:

'I feel supported. Especially the speech meant a lot to me. For me it is important to hear others saying that God loves me.' (Boy, 18 years, University of Applied Sciences)

Or:

'In fact, I want clarity about God. It does not matter to me whether God exists or not. I just want to know. But no one can guarantee me anything. And it scares me a bit, because I fear letting go of what is familiar to me.' (Girl, 19 years, University of Applied Sciences)

\section{Knowledge about and insight into God}

The second learning product, 'knowledge about and insight into God', refers to the reflections of adolescents on new or renewed insight into who God is. This insight can be cognitively or affectively based. This act of reflecting mostly starts when the interviewer asks questions such as 'How is the youth worship related to faith for you?' or 'Can you explain whether for you this gathering is related to God?' Often the 'vertical' reflection is initiated by the interviewer's question; however, sometimes adolescents spontaneously reflect on this dimension. The meanings adolescents give to the discovery of who God is, have two poles: one of certainty and one of doubt. The following quotations illustrate this product:

'This youth event, with so many people, proves for me that God really exists.' (Girl, 19 years, University of Applied Science)

'I really doubt whether God does exist. And I realize that when it is about God in the way of "it says in the Bible", I experience a feeling of resistance. I don't think I believe it. I like the themes and discussions, but the moment they 'drag in' God ... I don't really know if I believe this.' (Girl, 18 years, High School)

Another example is an adolescent who focuses on the instance in the sermon about a navigation system which struck home with him:

'You know how it works. And then you start thinking. Does God work the same way? That system leads you to where you want to go ... I can try to choose my own way, but God calls me back to his. And no matter which way I go, God stays with me.' (Girl, 19 years, University of Applied Science)

Yet whilst we cannot definitively decide, on the basis of our sources, whether this adolescent discovered an existential relationship with God, we suppose that this element of 'insight' possibly refers to this existential level.

\section{Religious and social-ethical applications}

The last of the 'distinguished' learning products is about the application of faith. The content of 'what to do' is important for adolescents and is connected to what we call 'the religious application in relation to God' and the 'socialethical application in daily life'. The first application refers to contents as the necessity of praying or Bible reading, but also such contents as a call to 'decide for God' or 'witnessing', and 'finding real faith'. The second application is the social-ethical application in their own life concerning friendship, global climate change, et cetera. It is about 'living consciously', 'finding your own way', 'paying attention to others'. Both applications may be accents in one and the same worship. What is offered and appropriated can also depend on the dominant perspectives in the congregation, for example the themes of 'occultism' and 'evangelising' are more popular in conservative congregations than in more mainstream or liberal congregations. A contrast with this aspect of 'application' is 'not applying in life', which we coded once when an adolescent explicitly separated Sunday and Monday. Indeed, we mention it here only because of our supposition that a separation between faith and life holds for more adolescents.

\section{Relevance of tradition}

The relevance of tradition is a learning product that refers to quotations and observations which speak about the importance of something old that is translated to a new context, or of something new that is connected with the 
past, for example a youth worship service in which Luke is presented as a modern doctor and historian. An important learning product is that the Bible, and also musical tradition and the actual church building, have relevance for modern people, for example the reflections of adolescents on an old church building in which modern liturgical performances happen. 'A church is not necessarily boring. This church with the old and modern together gives meaning to Christmas'. Old and new in combination tell their own story and thus adolescents learn ways to connect the old and the new by giving meaning to it. Re-traditionalising or re-invention are important concepts to understand this learning product (Hobsbawn \& Ranger 1992).

\section{Rules and freedom}

What is remarkable in the aspect of 'application' are the connotations of things you have to do in life and faith or the release from this 'having to' obligation. These ways of appropriation happen in the broad spectrum of the Protestant context in different manners. Some relate explicitly to the topic of 'having to' do what Jesus does, others discuss what the church or parents stress as important, and yet others stress their own ideas. Adolescents seek ways to integrate faith in life and some refer to a framework of rules. In one youth worship service with the theme 'Who navigates?', a respondent stressed that the most important thing for her was that you 'have to follow Jesus'. Her friend was triggered by the words of the minister about the importance of Bible reading. She said, 'I have to read the Bible more than I do now'. This topic of 'rules and freedom' is not only approached by the learning product of application, but also by the aspect of 'pluralism', for example how does your contact with people who have other opinions influence your own opinions? The following example from the interview data also indicates the topic of 'freedom and rules'. Firstly, a youth leader explains that Jesus asks Blind Bartimaeus, 'What can I do for you?' The explanation of the youth leader changes the perspective of a girl:

'I learned that Jesus said, "what can I do for you" and did not say

"what do you have to do?" That is what I used to think ... that you should follow rules.' (Girl, 15 years, High School)

Here, she emphasises the word 'rules'. The change of perspective in this example may be considered a learning product.

The importance of 'rules and freedom' is not only noticed in the interviews but also in the analysis of the participant observations. Many themes in youth worship gatherings focus on a specific Christian lifestyle and on its boundaries and spaces. Another example of this is when a youth leader emphasises that there are no rules, but it is freedom that matters. This results, for example, in the fact that adolescents in that congregation are allowed to have a key to the youth meeting place next to the church. The aspects of rules and freedom described lead to a theological discussion about the theme of freedom of a Christian. This is an important content in youth worship. What does this freedom mean in today's postmodern world? What are the spaces and boundaries in an age of pluralism? On the basis of the interviews, we regard youth ministry gatherings as an important place to reflect critically on the ways of behaving and believing.

\section{Discussion}

\section{Locating empirical results in theoretical views}

In the debate about the functionality of liturgy, we take the educational function of youth worship seriously. On the basis of the empirical analysis and in line with the recent perspectives on learning, learning is not reduced to its contents, but learning impulses are integrated in the research process.

In this section, we sum up a few explanations for the importance of learning faith in youth worship. In churches, one can often hear statements such as 'young people want to experience' or 'the fun factor is important for youth worship gatherings'. We agree with both statements, but also prove that youth worship cannot be approached in a one-sided manner, focusing only on the dimension of fun or experience, for adolescents in youth worship want to think about various topics and themes in depth just as much. Both an experiential and a reflexive-cognitive process appear equally important in the participation of adolescents in youth worship. A reflection on the importance of 'learning faith' leads to the following possible explanations, the first of which is that the importance of learning faith can be clarified by keeping in mind that adolescents go to school and learn to evaluate with criteria of improvement and development.

A second explanation is probably psychological in nature, namely, that the cognitive development of adolescents causes them to make special use of their newly developed cognitive skills of reflection and argumentation. Here, we refer to the analysis of the psychologist of religion, R. Nauta (2001:94-95), whose reflection on 'ritualising that agrees with the lifecycle' explains 'debate' as a ritual function in the socialisation of the initial puberty and adolescence. The dominant ritual of debate is necessary for the development of an ideology. This ritual strengthens convictions because it regulates meetings with adolescents and adults who share convictions and ideas. So the debate supports the 'solidarity of conviction'. The ritual underlines the consciousness of one's identity by exploring and cherishing the community with others with whom one can identify and who are of one mind (Nauta 2001:94-95). From our research, we conclude that the dialogical quality connects with the importance of the recognition of peers. This recognition yields openness; however, adolescents do not only stress this aspect of recognition and being of one mind, but also that there is room for varying opinions, personal contributions and private appropriations. They learn what pluralism means and want to learn from pluralism, especially in the case of events. We add the remark that not only is the peer perspective important in liturgical conversations, but that the role of the coach, an adult youth leader, is also crucial 
as a critical factor in the process of introducing elements from tradition, the Bible and other perspectives. Otherwise, a conversation might lack engagement.

A third possible explanation is that not all respondents believe in God, as they themselves admit. Some doubt whether they believe or whether God exists. Learning faith can be considered a process of acquiring information about faith. On the basis of the empirical results, we introduce a missionary perspective on learning faith in youth worship. We argue that the missionary perspective on worship does not primarily have as a target group unbelievers or the socalled 'unchurched' people, but adolescents who are not sure as yet whether they believe or not. In the data, different aspects of uncertainty with regard to faith identity are discovered: uncertainty about faith, doubt about the existence of God or the relation of adolescents with God, uncertainty about what faith means to them or how to practice faith. Many participants in youth worship are neither unbelievers nor unchurched, but are adolescents seeking or developing their (faith) identity.

A fourth aspect is the contrast with a 'regular' service that adolescents experience. The contrast is that youth worship uses 'understandable language' and openness toward adolescents, enabling them to explore and contribute something themselves. The 1960s are regarded as the turning point in the direction of the expressive and reflexive subject. The Dutch theologian, H. Berkhof (1914-1995), has reflected on the dialogical subject with regard to worship. He does not consider the conversation to be an adequate substitution of the sermon, but a prolongation. Berkhof (1985:353-356) regards both as a 'mediation of salvation'. In the conversation, the application comes to be more extensive, he argues. The sermon without conversation may be 'blown away' and the conversation without the sermon as background may lose its engagement (1985:353). We regard these observations as both critical and complementary thoughts concerning the differences between youth worship services and 'regular' services.

A fifth influence on the importance of learning faith, we suppose, may be that the respondents who participated in the research are brought up within a Protestant context, in which there is traditionally an emphasis on the 'verbaldiscursive elements in liturgy'.

A sixth aspect is that the boundaries between youth worship services and religious education or catechism fade away. Some youth worship services have characteristics of catechesis and, similarly, catechesis may incorporate elements of worship. The following question then arises: Is there a point at which youth worship is no longer worship? And is it useful to speak of more or less 'worship' qualities in youth worship? In this article, we confine ourselves merely to raising the question, but we aim to elaborate on this in future research.
A seventh, and perhaps final, explanation is that it turned out that youth worship has the didactical quality of practicing faith. Learning faith is inherent in youth worship, although the forms and contents vary in different kinds of youth worship. And in a secularised context this didactical quality of worship is likely to become more important: there simply is no general common knowledge of Christian faith anymore. These reflections indicate the faith of adolescents as related to youth worship. The faith of adolescents is, of course, not a homogeneous topic - many accents and perspectives are possible. During our research, it became clear that discovering is an important element in the faith of adolescents, as is the discovery of whether God exists and how God acts. Another important topic is the development of an orientation and attitude in relation to God and an orientation in daily life by means of dialogue, sermons, speech, musical performances, et cetera.

\section{Conclusion}

As mentioned, Barnard and Wepener describe cracks in the understanding of the maxim of the uselessness of liturgical ritual. They emphasise that the starting point should be that liturgy is useless, but they also argue that liturgy does have functional aspects and that in different contexts liturgy has different functions. In the context of youth worship, we conclude that the educational function of worship is apparent. We took up Astley's characterisation of the language of liturgy as 'performing non-cognitive'. The learning process in liturgy does not, in the first place, include cognitive elements, but primarily it creates basis attitudes for being a Christian. We agree with Astley that within that spiritual framework there can be explicitly cognitive aspects. We also conclude, firstly, that in youth worship the cognitive and reflexive element is important, although this appeared to be more central in the participation in the youth worship services than in youth worship events, and, secondly, we conclude that the explicit aspect in learning is a main approach. This is not at variance with the importance of a spiritual and ritual embedding of religious learning. However, for young people in both secular and Protestant contexts, the cognitive and explicit within liturgical ritual are important perspectives in their education in faith.

\section{Acknowledgements Competing interests}

The authors declare that they have no financial or personal relationship(s) which may have inappropriately influenced them in writing this article.

\section{Authors' contributions}

Both authors are both responsible for the research design. P.M.S. (Protestant Theological University) collected and analysed the empirical data, whilst M.B. (Protestant Theological University) fulfilled the role of supervisor involved in the research. 


\section{References}

Astley, J., 1984, 'The role of worship in Christian learning', Religious Education 79(3), 243-251. http://dx.doi.org/10.1080/0034408400790208

Barnard, M. \& Wepener, C., work in progress, to be submitted during 2012, 'Reclaiming space for learning in liturgical contexts: Cracks in the maxim of the uselessness of liturgical ritual'.

Barnard, M., 1998, 'Prediking', in P. Oskamp, N. Schuman \& M. Barnard (eds.), De weg van de liturgie: Tradities, achtergronden, praktijk, pp. 210-216, Meinema, Zoetermeer.

Berkhof, H., 1985, Christelijk geloof, Callenbach, Nijkerk.

Hermans, C., 2001, Participerend leren: Grondslagen van religieuze vorming in een globaliserende samenleving, Uitgeverij Damon, Budel.

Hobsbawn, E. \& Ranger, T., 1992, The invention of tradition, Cambridge University Press, Cambridge.
Klie, T. \& Leonhard, S. (eds.), 2008, Performative religionsdidaktik: ReligionsästhetikLernorte-Unterrichtspraxis, Kohlhammer, Stuttgart.

Lave, J. \& Wenger, E., 1991, Situated learning: Legitimate peripheral participation, Cambridge University Press, Cambridge.

Miedema, S., 2002, 'Overdracht of toe-eigening', in S. Miedema \& H. Vroom (eds.), Alle onderwijs bijzonder: Levensbeschouwelijke waarden in het onderwijs, pp. 73-96, Meinema, Zoetermeer.

Nauta, R., 2001, 'Mensen', in M. Barnard \& P. Post (eds.), Ritueel bestek: Antropologische kernwoorden van de liturgie, pp. 93-98, Meinema, Zoetermeer.

Roebben, B., 2007, Godsdienstpedagogiek van de hoop: Grondlijnen voor religieuze vorming, Acco, Leuven.

Sonnenberg, P.M. \& Barnard, M., 2008, 'God talk between beat and silence: Presentatie van eeen PhD-project over youth worship in Protestantse contexten', Jaarboek Voor Liturgie-onderzoek 24, 177-197.

Van Ruler, A.A., 1969, Theologisch, werk 1, Callenbach, Nijkerk.

Van Ruler, A.A., 1972, Theologisch, werk 4, Callenbach, Nijkerk. 